\title{
COMPOSITION, DENSITY AND BIOMASS OF ZOOPLANKTON IN CULTURE PONDS OF Litopenaeus vannamei (DECAPODA: PENAEIDAE) IN SOUTHERN BRAZIL
}

\author{
CARDOZO, A.P.; BERSANO, J.G.F. \& AMARAL, W.J.A. \\ Fundação Universidade Federal do Rio Grande \\ Departamento de Oceanografia, Laboratório de Zooplâncton \\ Avenida Itália km 8 - Campus Carreiros \\ Caixa Postal, 474 CEP 96.201-900, Rio Grande/RS, Brasil \\ A/C: Alessandro Pereira Cardozo (Autor de contato) \\ e-mail: ocalessandro@yahoo.com.br
}

\begin{abstract}
Cardozo, A.P.; Bersano, J.G.F. \& Amaral, W.J.A. 2007. Composition, density and biomass of zooplankton in culture ponds of Litopenaeus vannamei (Decapoda: Penaeidae) in southern Brazil. Braz. J. Aquat. Sci. Technol. 11(1):13-20. ISSN 1808-7035. Litopenaeus vannamei is the most cultivated shrimp species in Brazil, being fed basically on high protein formulated diets. However, some studies have shown that the natural zooplankton found in shrimp ponds can be part of the diet of this crustacean. In this study, the zooplankton composition, density and biomass were evaluated for two shrimp ponds from a shrimp farm in the Patos Lagoon estuary, in southern Brazil $\left(32^{\circ} 00^{\prime} \mathrm{S}\right.$, $51^{\circ} 59^{\prime} \mathrm{W}$ ) between $11 / 09 / 2005$ and $01 / 20 / 2006$. The two ponds were sampled over three consecutive months using a zooplankton net of $150 \mathrm{~cm}$ total length, $30 \mathrm{~cm}$ mouth diameter and $140 \mu \mathrm{m}$ nylon mesh size. All the zooplankton samples were preserved in formaldehyde solution at a final concentration of $4 \%$ and transported to the laboratory, where the composition, density and biomass (wet and dry weight) were assessed. Copepoda and Cladocera were the most frequent groups, while the most abundant species were Acartia tonsa, Pseudodiaptomus richardi and Moina micrura, species commonly found in the Patos Lagoon Estuary. The density values obtained in the ponds were higher than those usually found in the estuary during periods of maximum production, reaching 278 org. L-1 in 11/18/2005 (pond 1), and 277 org. $\mathrm{L}^{-1}$ in 12/08/2005 (pond 2), suggesting that the zooplankton grow well in the shrimp ponds. Zooplankton biomass in the ponds was also relatively high, ranging from 0.15 to $13.28 \mathrm{~g} \cdot \mathrm{m}^{-3}$ of wet weight and 0.01 to $2.72 \mathrm{~g} \cdot \mathrm{m}^{-3}$ of dry weight, following the same tendency of density. These results clearly indicate that the natural zooplankton occurring in the shrimp ponds represents a potential food source for the shrimp larvae and juveniles during the first months of culture.
\end{abstract}

Keywords: Copepoda, Cladocera, Abundance, Shrimp

\section{INTRODUCTION}

In recent decades, shrimp farming has been attracting considerable attention due to its remarkable growth worldwide (FAO, 2006). The main cultivated species are Penaeus monodon, Fenneropenaeus chinensis and Litopenaeus vannamei, the latter alone being responsible for $80 \%$ of the world production (FAO, 2006). In Brazil, L. vannamei is the most cultivated species and the Brazilian production has been increasing at a remarkable rate of about 40 to $80 \%$ a year, representing nowadays $5 \%$ of the world production (FAO, 2006).

L. vannamei is a marine species from the Pacific Ocean more specifically from the west coast of Mexico to the coast of Peru, showing great resistance to varying culture conditions, tolerating a wide range of temperatures and salinities (Bray et al., 1993; PoncePalafox et al., 1997). These characteristics are especially attractive because they reduce entrepreneurial risks and increase the chances of profitability. This explains why L. vannamei, although exotic, is the main cultivated species in Brazil, given that other native penaeid shrimps are less tolerant to varying culture conditions (Brito et al., 2000).

During the first months of culture in earthen ponds the feeding base of this species is composed partially of the natural food produced in the pond (Anderson et al., 1987; Nunes et al., 1997; Martinez-Cordova et al., 1997; Rothlisberg, 1998), zooplankton for instance, and partially by supplementary feeding with commercial formulated feeds.

Chen \& Chen (1992) recorded that $P$. monodon juveniles are efficient zooplankton predators, and that predation efficiency is related to size, since larger shrimp juveniles ingested higher amount of prey. For the blue shrimp Litopenaeus stylirostris, higher values of growth and food conversion rates in ponds have been found where the phytoplankton production was stimulated 
through out fertilizations with urea and triple super phosphate (Martinez-Cordova et al., 1997).

Martínez-Córdova \& Pena-Messina (2005), on comparing semi-intensive monoculture and polyculture of $L$. stylirostris and $L$. vannamei, found lower zooplankton densities in ponds with monospecific cultures of $L$. vannamei, suggesting that this species is an efficient zooplankton predator.

Regarding the zooplankton, studies carried out in Australia have shown that copepods are dominant in marine shrimp ponds (Coman et al., 2003), generally reflecting the composition of the environment from where the water is pumped. In these studies reductions of zooplankton biomass after the introduction of some postlarvae species, such as Penaeus japonicus (Coman et al., 2003) and P. monodon (Preston et al., 2003), were observed, indicating their predation on zooplankton.

Besides the importance of zooplankton as a food source for shrimp in growth ponds, the use of these organisms, mainly copepods, as live food in marine aquaculture has been receiving great attention in the last years (Delbare et al., 1996). These organisms are rich in phospholipids, highly unsaturated fatty acids (HUFA) and natural antioxidants, being nutritionally superior to rotifers and Artemia nauplii (Watanabe et al., 1983; Sargent et al., 1997; Stottrup \& Nosker, 1997).

Several studies have shown that copepods have a higher nutritional value, when compared to Artemia and rotifers (Helland et al.; 2003), and also the increase in the success of some larvicultures when copepods are used (Payne et al., 1998; Schipp et al., 1999; Payne \& Rippingale, 2000).

In the southern region of Rio Grande do Sul state in southern Brazil, shrimp culture farms situated in the Patos Lagoon estuary (PLE), have been operating since 2000. The main cultivated species is $L$. vannamei, due to the availability of larvae and also because of its tolerance to salinity variations. In the PLE, flood and ebb tide regimes are controlled mainly by winds and rainfall in the draining basin (Garcia, 1997), leading to great salinity variations, with high salinities associates with periods of flood and lower salinities related to periods of ebb tide (Niencheski \& Baumgarten, 1997).

The zooplankton of the PLE is dominated mainly by copepods (Montú, 1980), however, frequent salinity variations observed in the area, can affect the zooplankton composition. During periods of flood tide, organisms of marine origin such as Calanoida copepods can be dominant, while cladocerans and Cyclopoida copepods are commonly associated with low salinities during ebb tide periods (Montú et al., 1997).

In general the shrimp farms in the region pump water directly from the PLE, and thus the zooplankton composition in the ponds is expected to be similar to that found in the PLE at the moment of pumping.
However, a substitution of species could possibly occur in the ponds, according to temporal salinity changes.

In Brazil, there are no studies that evaluate the growth potential of zooplankton in marine shrimp culture ponds, as well as its role as a live food source. In this context, the aim of this study was to evaluate the composition, density and biomass (wet and dry weight) of zooplankton in culture ponds of the white shrimp Litopenaeus vannamei in the PLE southern Brazil.

\section{MATERIAL AND METHODS}

The present study was carried out at Carcibrás shrimp farm in São José do Norte - RS, Brazil $\left(32^{\circ} 00^{\prime} S\right.$, $51^{\circ} 59^{\prime} \mathrm{W}$ ). Two earthen ponds, pond 1 (P1) (area of 2.2 hectares) and pond 2 (P2) (area of 3,8 hectares) both with an average depth of $0.8 \mathrm{~m}$ were used and prepared in a similar way before being flooded.

Lime was added for correction of soil $\mathrm{pH}$ and disinfection. After that, the bottom of the ponds was ploughed with the use of a tractor in order to mix lime with the soil. The flooding was started with water being pumped directly from the PLE to a higher ground reservoir and then distributed by means of channels made of masonry and filtered through a net of $600 \mu \mathrm{m}$ mesh size to avoid the presence of possible predators, such as juvenile fish and small crustaceans.

After a period of seven days the total flooding of the $\mathrm{P} 1$ was completed, and the zooplankton sampling program was initiated in 11/09/2005. For P2, due to its larger size, was more time required to complete the flooding process and the zooplankton sampling began in $11 / 16 / 2005$.

Other than the size difference between the two ponds, they were also different in their soil composition. Both were characterized by sandy soil, but P1 was situated on lower ground and had a higher amount of organic matter due to its proximity to the PLE.

During the sampling period no water renewal was carried out in the ponds, only replacements of the losses due to evaporation and infiltration of the slopes, resulting in the introduction of about $10 \%$ of the total volume of the ponds per week. Five fertilizations took place in $\mathrm{P} 1$ on 16 November, and 16, 26 and 27 December 2005 and 05 January 2006, with the addition of urea and triple super phosphate in a ratio of 10:1. No fertilizations took place in P2.

Ten day old post-larvae (PL-10) were bought from a larviculture company and introduced in the ponds. In P1, 660,000 PL-10 were introduced in 11/18/2005, reaching a density of $30 \mathrm{PL}-10 . \mathrm{m}^{-2}$. In P2, 980,000 PL10 were stocked in 12/08/2005, giving a final density of 25 PL-10. $\mathrm{m}^{-2}$. 
Zooplankton samplings were carried out by transversal tows made in the opposite direction of predominant winds direction, which were predominately from the NE quadrant during the study period. In each pond, three sampling points were selected, one point next to the water inflow, another in the central region of the pond, and the third point next to the water outflow. The sampling schedule was every two to four days in the first month, and an average of every 8 days during the remaining period.

After zooplankton sampling, temperature, salinity, $\mathrm{pH}$ and oxygen dissolved were measured in the surface waters. For temperature measurements a mercury thermometer (Incoterm 99370/02) was used, the salinity was measured with a hand refractometer (Atago S/Mill$\mathrm{E}), \mathrm{pH}$ with a manual $\mathrm{pH}$ measurer (ATC F-HI98127) and the oxygen dissolved with the use of an oximeter (Hanna F-HI9147K).

Sampling took place at night because both zooplankton organisms and shrimps were more active in the water column during that period. The samples were collected with a $1.5 \mathrm{~m}$ length cylindrical-conical net of $30 \mathrm{~cm}$ mouth diameter and $150 \mu \mathrm{m}$ mesh size. A $20 \mathrm{~cm}$-diameter buoy was attached to the mouth of the net to keep it next to the surface.

In the first seven days of samplings the filtered volume was estimated through the calculation that uses the covered distance and the area of the net mouth. After this period a flowmeter was connected to the net mouth to estimate the sample filtered volumes. Due to the fact that two methods were used to obtain filtered volumes, a test sample was carried out with and without the flowmeter to test for differences. But, no differences were found between the two volume estimates, probably because of the low water circulation inside the ponds.

After samples were taken, they were transferred to one-liter plastic bottles and immediately fixed in a buffered formaldehyde $4 \%$ solution. Two days after sampling the volume in the plastic bottles was transferred to glass bottles and taken to the laboratory. For the qualitative and quantitative analyses, the samples were fractionated with a Motoda-type quarter and transferred to a known volume beaker from which aliquots of $10 \mathrm{ml}$ were taken with a sub-sampler (Boltovskoy, 1981). The sub-samples were transferred to Bogorov's counting chambers and examined under a stereoscopic microscope.

In order to assess the zooplankton biomass in terms of grams of wet weight, the whole sample was used. For this, the collected material was retained on a preweighed sieve with a screen aperture of $50 \mu \mathrm{m}$, toweldried to remove excess water, and weighed on an analytical scale Mars model LC- 5 (precision of $0.5 \mathrm{~g}$ ).

To determine the biomass in dry weight, an aliquot was removed from the samples and immediately filtered in previously weighed on fiber glass filters $(0.45$ $\mu \mathrm{m})$. To maximize the filtering a Quimis vacuum pump, model 355B, with one HP was used. Then the filters were placed in an oven at $60^{\circ} \mathrm{C}$ for 14 hours, being kept after this period in a desiccator with blue silica-gel for 24 hours. After that period, the dry weight was determined on an Gehak analytical scale (precision of $0,001 \mathrm{~g}$ ) model AG200 according to the method of Beers (1976). To correct the weight loss (wet and dry) of the organisms due to fixation with formaldehyde $4 \%$, a loss of $35 \%$ of the weight of the organisms was considered, following the recommendations of Durbin \& Durbin (1978).

In order to obtain the prosome length, total length and body width of the dominant species, pictures of the organisms ( $n=30$ for each species) were taken with a video camera (Sony CCD-IRIS) coupled to a stereoscopic microscope (Olympus $U$ - CMAD3) connected to a computer. The measurements were obtained with the image analysis program Image-Pro Plus 4.1.

The density and biomass values in the two ponds were compared with two-way ANOVA, followed by the posteriori Tukey's test when significant differences $(p<$ 0.05 ) were observed.

\section{RESULTS}

Temperature and salinity values varied during the study with salinity staying around 4 between 11/09/2005 and 12/08/2005 in P1, and between 11/16/2005 and 12/ $01 / 2005$ in P2 (Figs. 1-2). After this period a gradual increase in salinity was observed in the two ponds until the end of the experiment, with maximum values of 14 for both P1 (Fig. 1) and P2 (Fig. 2). The temperature did not show great variations during the study period. The lowest water temperatures recorded were $18^{\circ} \mathrm{C}$ for $\mathrm{P} 1$ on $11 / 09 / 2005$ (Fig. 1 ), and $23.5^{\circ} \mathrm{C}$ on $12 / 15 / 2005$ for P2 (Fig. 2). The maximum temperature recorded was $27.5^{\circ} \mathrm{C}$ for both ponds.

The values of dissolved oxygen varied between 6.2 and $9.7 \mathrm{mgO}_{2} \cdot \mathrm{L}^{-1}$ in $\mathrm{P} 1$, and between 8.6 and 10.8 $\mathrm{mgO}_{2} \cdot \mathrm{L}^{-1}$ in $\mathrm{P} 2$, with maximum values occurring on $12 /$ $01 / 2005$ in both ponds. For $\mathrm{pH}$, alkaline values were recorded in $\mathrm{P} 2(8.6$ - 10.8) whereas in $\mathrm{P} 1$ the values stayed between 7 and 8.7 with maximum values registered in 12/15/2005 in P1 and 12/08/2005 in P2.

In this study 31 taxa were identified, 19 to specific level, 2 to genus level and 10 to group level. The most frequent organisms were the Calanoida copepods Acartia tonsa, Pseudodiaptomus richardi and Notodiaptomus incompositus, the Cyclopoida copepods Acanthocyclops robustus and Microcyclops furcatus and also, the cladoceran Moina micrura. Together with these organisms, Calanoida and Cyclopoida copepodits were 
present in all samples in both ponds throughout the study period, being in some occasions the most abundant organisms.

For the total zooplankton mean density, the values ranged between 2 and 278 org. $\mathrm{L}^{-1}$ in $\mathrm{P} 1$, while in $\mathrm{P} 2$ the values varied between 34 and 277 org. L $^{-1}$ (Fig. 3). Even with the occurrence of 31 taxa during the study period, only six of these taxa were the most abundant in terms of density.

Of the most abundant organisms, cladoceran $M$. micrura showed higher density values at the beginning of the study period, reaching in P2 a peak of 233 org. $\mathrm{L}^{-}$ 1 on 11/16/05 (Fig. 4). During the periods of high abundance it was also recorded the presence of ephippia containing resting eggs of $M$. micrura.

Of all the zooplanktonic organisms, copepodits of the Calanoida and Cyclopoida orders showed the highest densities during the whole studied period, corresponding to $98 \%$ of total zooplankton on some

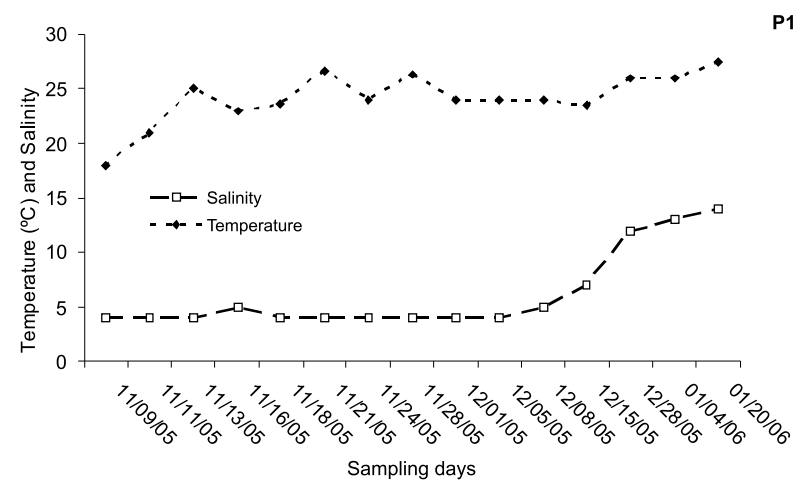

Figure 1. Temperature and salinity variation in culture pond $n^{\circ} .1$ (P1) of Carcibrás Shrimp Farm, São José do Norte - RS, between november of 2005 to january of 2006.

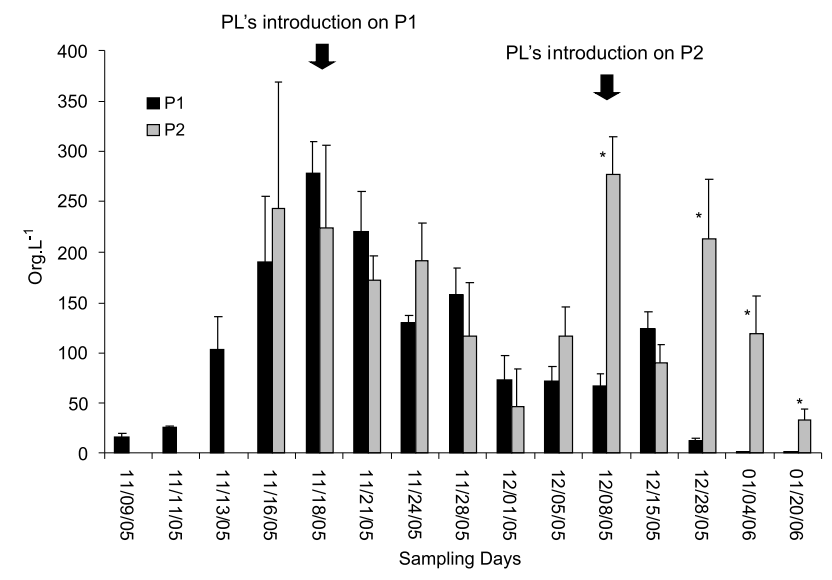

Figure 3. Total zooplankton density in org. $\mathrm{L}^{-1}$ (mean \pm standard deviation). * - denotes significant differences between ponds (twoway ANOVA, $p<0.05)$. Arrows indicate post-larvae introduction. occasions, with densities of 311 org.L-1 (Fig. 5). The copepods $M$. furcatus and $A$. robustus, had higher densities between $11 / 09 / 05$ and $12 / 08 / 05$, reaching maximum values of 13 org. $\mathrm{L}^{-1}$ on 11/24/05 (Fig. 6 ) and 8 org. $\mathrm{L}^{-1}$ on $11 / 28 / 05$ (Fig. 7) respectively, for $\mathrm{P} 2$.

As salinity increased throughout the study period, a species substitution was observed. The species of freshwater origin were gradually replaced by the copepods $A$. tonsa and $P$. richardi, species more adapted to tolerate higher salinities. $P$. richardi reached maximum densities of 32 org. L- $^{-1}$ (Fig. 8) while $A$. tonsa reached densities of 92 org. L-1 (Fig. 9).

The substitution of freshwater organisms by typically estuarine species was more markedly observed in P2, where typical salinities of the PLE were recorded for a longer period (Fig. 2). In this pond there was an increase in salinity from $12 / 01 / 05$ to $12 / 15 / 05$, and a clear drop in the abundance of $M$. micrura was recorded (Fig. 4), an important cladoceran of freshwater origin,

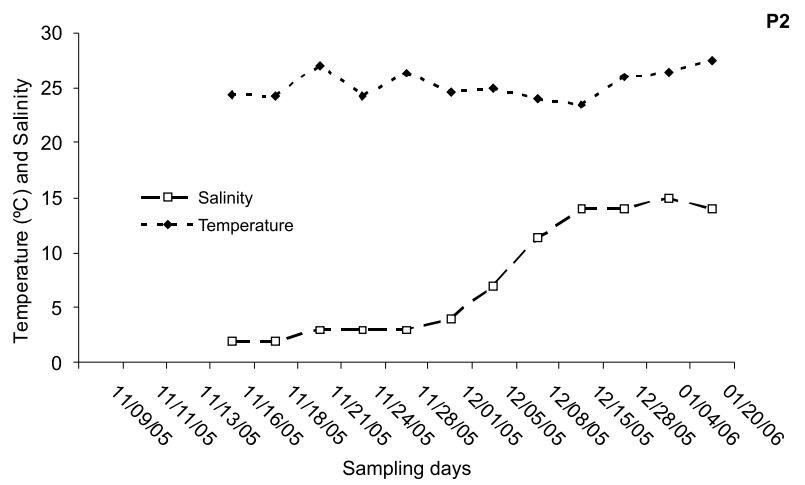

Figure 2. Temperature and salinity variation in culture pond $n^{\circ} .2$ (P2) of Carcibrás Shrimp Farm, São José do Norte - RS, between november of 2005 to january of 2006 .

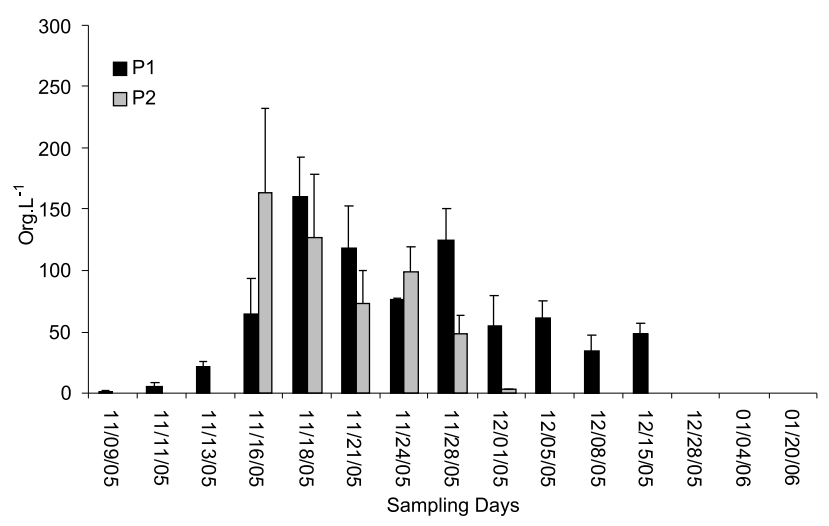

Figure 4. Mean density of Moina micrura in org.L-1 (mean \pm standard deviation). 
followed by an increase in the density of the coastal and estuarine copepod $A$. tonsa (Fig. 9).

The most frequent organisms recorded during this study were distributed in different size classes, since small copepodits with $490 \mu \mathrm{m}$ of total length (prosome + urosome), up to relatively large copepods with 1.4 $\mathrm{mm}$ of total length (Table 1).

Regarding the biomass, the wet weight values followed the same temporal pattern observed for the density in both ponds, with values ranging from 0.23 to $21.70 \mathrm{~g}^{-\mathrm{m}^{-3}}$ in P1 and from 1.28 to $20.43 \mathrm{~g}^{\mathrm{m}} \mathrm{m}^{-3}$ in P2 (Fig. 10). For $\mathrm{P} 1$, the highest density value recorded in $11 / 18 / 05$, was coincident with the highest value of wet weight. In contrast, for P2, the highest density found in $\mathrm{P} 2$, did not match with the wet weight peak. For this pond, the highest registered density value occurred in $12 / 08 / 05$, and the peak of wet weight in 11/24/05.

The mean values of biomass in dry weight were

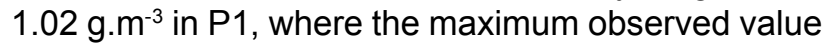
was $2.42 \mathrm{~g} \cdot \mathrm{m}^{-3}$, and the minimum was $0.10 \mathrm{~g} \cdot \mathrm{m}^{-3}$. For $\mathrm{P} 2$, the mean dry weight biomass during the period was

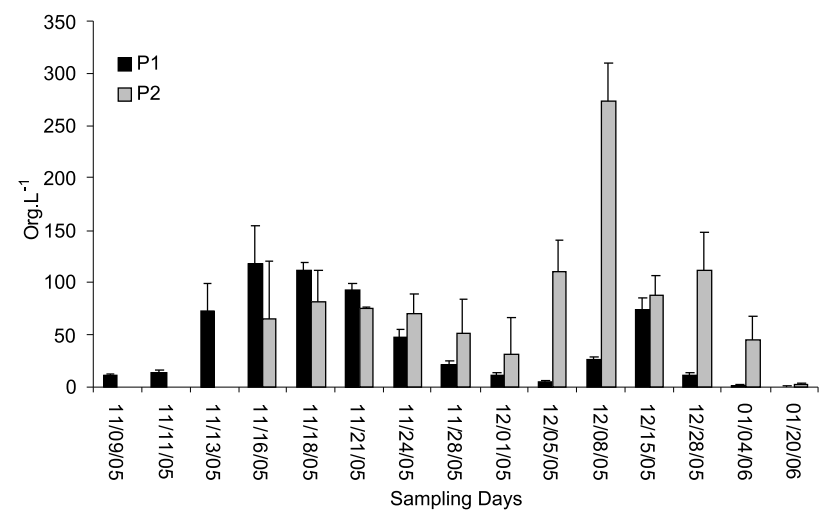

Figure 5. Mean density of copepodits in org. $\mathrm{L}^{-1}$ (mean \pm standard deviation).

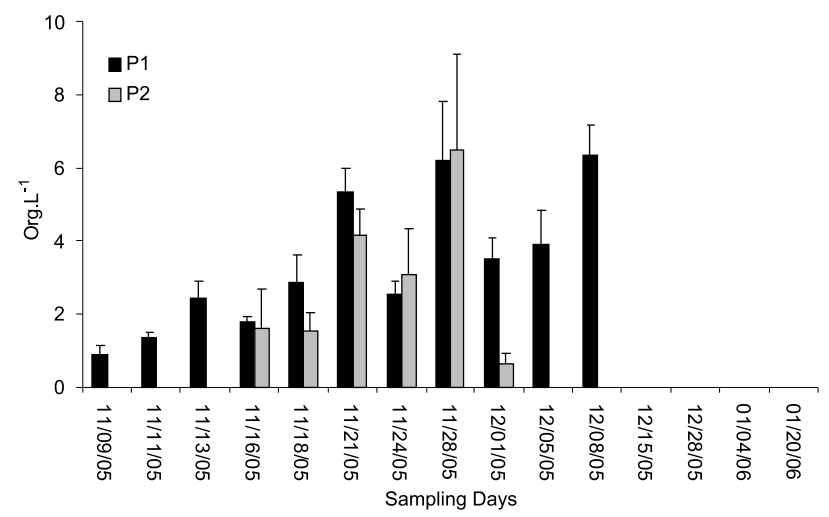

Figure 7. Mean density of Acanthocyclops robustus in org.L-1 (mean \pm standard deviation).
$1.23 \mathrm{~g} \cdot \mathrm{m}^{-3}$, with a maximum of $2.72 \mathrm{~g} \cdot \mathrm{m}^{-3}$ and a minimum of 0.53 g.m $\mathrm{m}^{-3}$ (Fig. 11).

\section{DISCUSSION}

The salinity variations recorded in the two ponds during this study possibly reflected the hydrological conditions of the water pumping region, the PLE, where daily and seasonal variations of salinity can occur (Niencheski \& Baumgarten, 1997). The water renewal of $10 \%$ per week along with evaporation losses, may have caused a gradual increase in salinity in both ponds. The small variation in water temperature observed in both ponds during this study was probably related to the constant and high temperatures that occurred during that summer.

The values of dissolved oxygen measured in the ponds, indicated that this parameter was not limiting for the organisms, since the lower values observed were close to $6 \mathrm{mg} \cdot \mathrm{L}^{-1}$. With regard to the $\mathrm{pH}$, the lower values

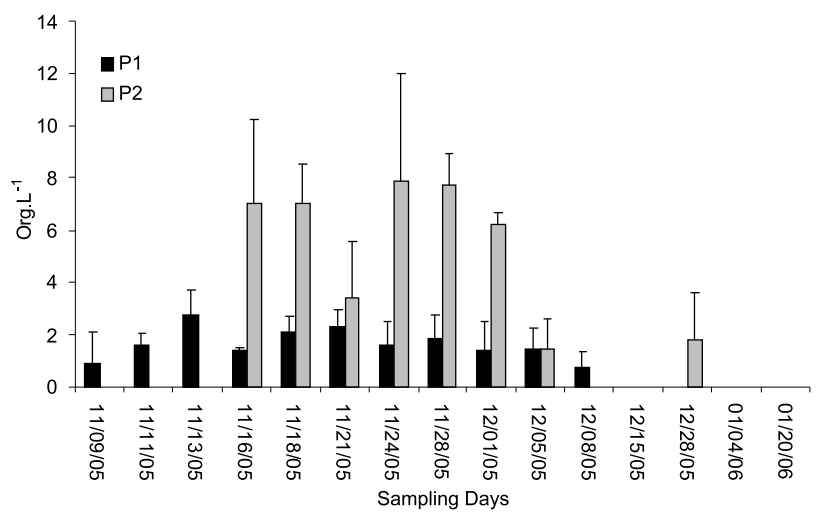

Figure 6. Mean density of Microcyclops furcatus in org.L-1 (mean \pm standard deviation).

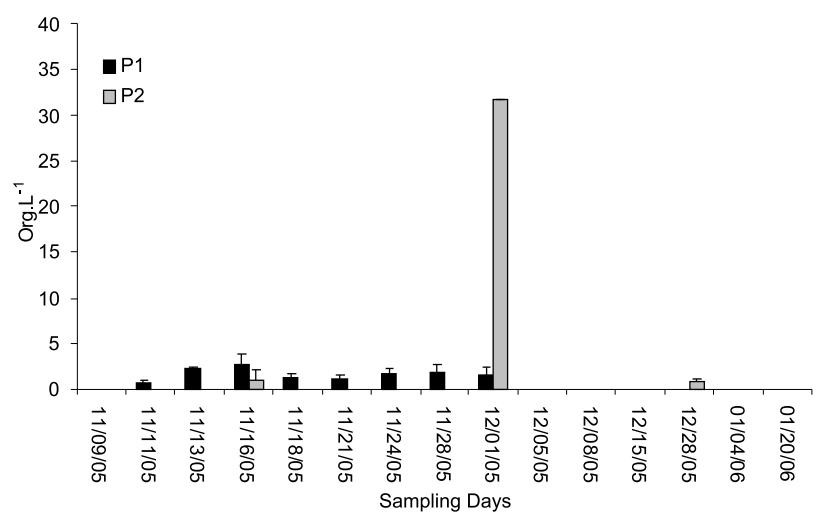

Figure 8. Mean density of Pseudodiaptomus richardi in org. $\mathrm{L}^{-1}$ (mean \pm standard deviation). 


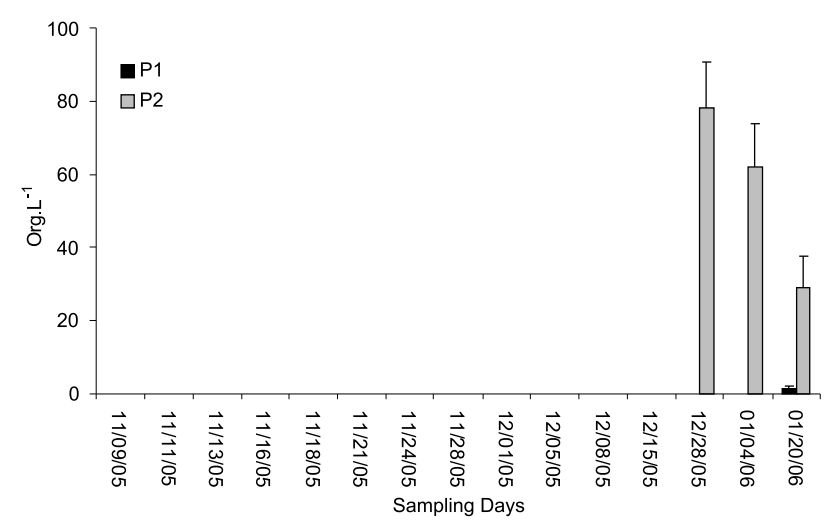

Figure 9. Mean density of Acartia tonsa in org. $\mathrm{L}^{-1}$ (mean \pm standard deviation).

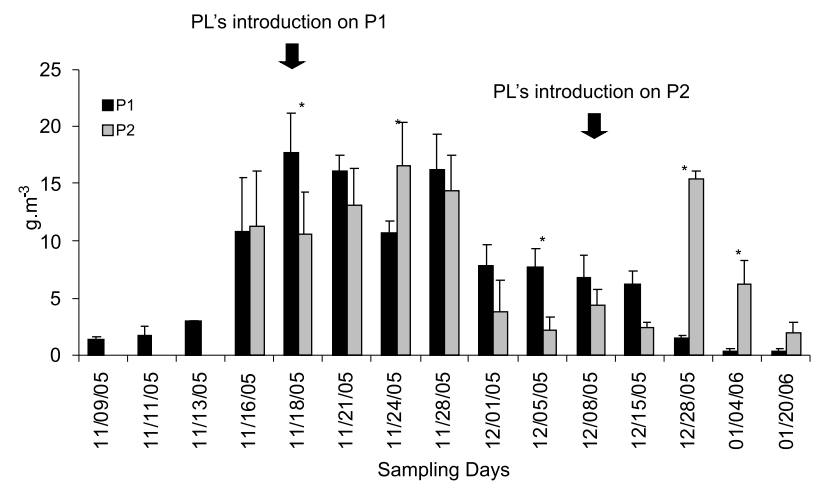

Figure 10. Wet weight biomass of total zooplankton in $\mathrm{P} 1$ and $\mathrm{P} 2$ in g. $\mathrm{m}^{-3}$. * - denotes significant differences between ponds (twoway ANOVA, $p<0.05)$. Arrows indicate post-larvae introduction.

recorded for $\mathrm{P} 1$ were probably a result of its soil which had great amount of organic matter due to its proximity to PLE. In P2, the values were always higher than 8 because this presented a sand sediment due to its higher quote to the PLE.

The species composition found in the ponds in the beginning of the study, presented organisms of freshwater origin, such as $N$. incompositus and $M$. micrura, and with the salinity increase, there was a substitution by species of marine origin, such as $A$. tonsa (Montú et al., 1997). This species can be considered truly eurihaline, being found in the PLE at salinity values from 0 to 35 (Montú, 1980). All the species recorded in this study have been found in the PLE by Montú (1980) and Montú et al. (1997).

The zooplankton density values observed in the ponds were higher than the value of 40 org. $\mathrm{L}^{-1}$ registered in the PLE by Montú et al. (1997). In this study mean densities of 96 org. $\mathrm{L}^{-1}$ in $\mathrm{P} 1$, and 158 org. $\mathrm{L}^{-1}$ in $\mathrm{P} 2$, indicate that in semi-closed environments as the earthen ponds, zooplankton can find favorable conditions for reproduction and growth, even considering the presence of predators such as shrimp larvae. The density values
Table 1. Size of the more frequent organisms (average \pm standard deviation). For copepods TL - Total length (Prosome + Urosome), $\mathrm{PL}$ - Prosome length, $\mathrm{W}$ - width. * For Moina micrura TL correspond to the total carapace length, form the top of the head to the tip of the spine.

\begin{tabular}{lccc}
\hline \hline \multicolumn{1}{c}{ Groups } & $\mathrm{TL}(\mu \mathrm{m})$ & $\mathrm{PL}(\mu \mathrm{m})$ & $\mathrm{W}(\mu \mathrm{m})$ \\
\hline Pseudodiaptomus richardi & $1.387 \pm 65$ & $924 \pm 42$ & $343 \pm 24$ \\
Acanthocyclops robustus & $1.085 \pm 133$ & $702 \pm 76$ & $415 \pm 37$ \\
Acartia tonsa & $938 \pm 96$ & $735 \pm 71$ & $249 \pm 18$ \\
Microcyclops furcatus & $828 \pm 87$ & $538 \pm 78$ & $311 \pm 35$ \\
Copepodits (Calanoida e Cyclopoida) & $580 \pm 90$ & $425 \pm 62$ & $172 \pm 23$ \\
Moina micrura & $716 \pm 69 *$ & - & - \\
\hline \hline
\end{tabular}

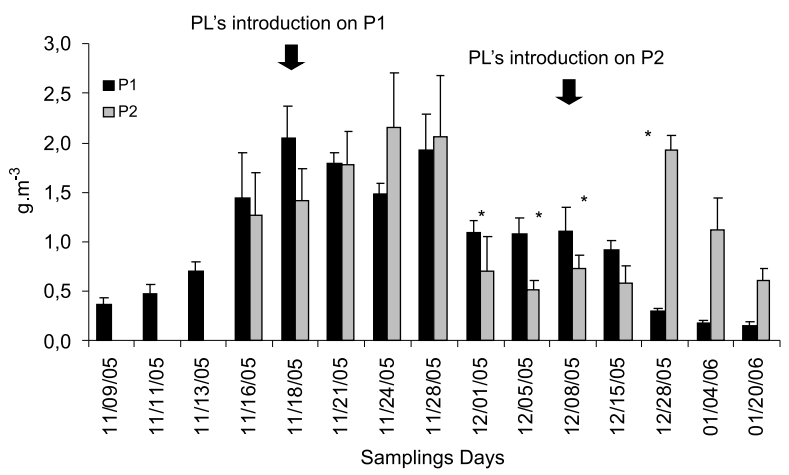

Figure 11. Dry weight biomass of total zooplankton in $\mathrm{P} 1$ and $\mathrm{P} 2$ in g. $\mathrm{m}^{-3} .{ }^{*}$ - denotes significant differences between ponds (twoway ANOVA, $p<0.05)$. Arrows indicate post-larvae introduction.

recorded in this study are the highest observed for the PLE region until now.

The observed drop in zooplankton density in P1 right after the shrimp PL introduction, represents a strong indication of predation on zooplankton, since at that time, salinity, one of the parameters that regulates the zooplankton composition and density, did not show great variations. The introduction of shrimp PL in $\mathrm{P} 2$, also seems to have led to a reduction in the total zooplankton density, giving support to the idea that in the first days in the ponds, zooplankton is an important alimentary item for the PL (Martinez-Cordova et al., 1997; Rothlisberg, 1998; Martinez-Cordova et al., 2002).

Besides this evidence, the post-larvae seem to have exerted selective predation upon zooplankton, given that for both ponds a marked reduction in the numbers of copepodits ( $580 \mu \mathrm{m}$ in size) was observed after the introduction of the post-larvae, suggesting a preference for organisms in this size class. This fact was more evident in P2, where the copepodits represented more than $90 \%$ of total zooplankton, and after the introduction of post-larvae showed a density reduction of $50 \%$.

However, it is important to highlight the fact that at the time of the PL introduction in P1, the P2 also showed a considerable decrease in the zooplanktonic 
density, even with the absence of PL. In this in case, the factor causing the zooplankton decline, was probably the overpopulation of cladocerans, since one of the most abundant organisms in this pond, the cladoceran $M$. micrura, showed the formation of ephippia, which are resting eggs that indicate unfavorable conditions for population growth.

When environmental conditions deteriorate due to overcrowding, lack of food, oxygen depletion and variations of other environmental conditions, cladocerans populations tend to produce the ephippia through sexual reproduction (Margalef, 1983; He et al., 2001). Given that great variations in the physical-chemistry parameters were not observed during the period of dominance of the cladocerans, their population collapse in P2 may have occurred due to the exhaustion of adequate food resources caused by overcrowding.

Therefore, variations in zooplankton abundance in shrimp ponds must be carefully interpreted, because besides the predation pressure exerted by the postlarvae, the reductions and increases in zooplankton density can also be related to natural processes of succession in recently colonized environments.

Opportunistic species can show population explosions that lead to a fast exhaustion of the system support capacity, occurring then a collapse of the population. Before reaching stable conditions, a system can endure many processes of succession that over time can culminate with a climax community (Odum, 1986). Concerning the zooplankton from shrimp ponds around the Rio Grande region, a climax situation would be unlikely to happen given the frequent salinity fluctuations recorded in the area and the short time duration of the ponds operation ( five months).

Even though shrimp ponds seems to favor the growth of zooplankton, the values of density and biomass of natural zooplankton produced in the ponds will probably vary according to geographical and regional conditions. On comparing to the results of this study with literature values, some authors have recorded lower zooplankton densities (Preston et al., 2003; Coman et al., 2003), while others have found higher values in shrimp ponds (Coman et al., 2006), including some extreme density peaks $\left(\sim 840\right.$ org. $\left.\mathrm{L}^{-1}\right)$ such as that registered by Martínez-Córdova \& Peña-Messina (2005).

This is probably related to the amount and quality of the available food for zooplankton in the ponds. Other than the intrinsic characteristics of each area, the production of zooplankton in culture ponds can be stimulated through fertilizations that increase phytoplankton productivity (Barbieri \& Ostrensky, 2002). In addition the use of organic inductors, can promote an increase in ciliate and flagellate communities in the ponds that stimulate the growth of zooplankton (Martinez-Cordova et al., 2002).
In conclusion, the results of this study indicate that in semi-closed environments with little water renewal, such as shrimp ponds, high zooplankton density and biomass can be reached. Thus, the natural zooplankton occurring in shrimp ponds represents a potential food source for the shrimp post-larvae and juveniles during the first months of culture in southern Brazil.

\section{REFERENCES}

Anderson, R.K.; Parker, P.L. \& Lawrence, A. 1987. A ${ }^{13} \mathrm{C} /{ }^{12} \mathrm{C}$ tracer study of the utilization of presented feed by a commercial important shrimp Penaeus vannamei in a pond growout system. J. World. aquacult. Soc. 18(3): 148-156.

Barbieri, R.C.J. \& Ostrensky, A. 2002. Camarões Marinhos - Engorda, Volume 2. $1^{\text {a }}$ Edição. Aprenda Fácil, Brasil. 252p.

Beers, J.R. 1976. Determination of zooplankton biomass. In: Steedman, H.F. (ed.) Zooplankton fixation and preservation, Monographs on Oceanographic Methodology. UNESCO, Paris. 3586pp.

Boltovskoy, D. 1981. Submuestro. In: Boltovskoy D. (ed.), Atlas del zooplancton del Atlantico Sudoccidental y metodos de trabajo con el zooplancton marino. Publ. Esp. INIDEP. 143-146pp.

Bray, W.A.; Lawrence A.L. \& Leung-Trujilio, J.R. 1993. The effect of salinity on growth and survival of Penaeus vannamei with observations in the interaction of IHHN virus and salinity. Aquaculture. 122: 137-146.

Brito, R.; Chimal M.-E. \& Rosas, C. 2000. Effect of salinity in survival, growth, and osmotic capacity of early juveniles of Farfantepenaeus brasiliensis (decapoda: penaeidae). J. Exp. Mar. Biol. Ecol. 244: 253-263.

Chen, Y.-L. L. \& Chen H.-Y. 1992. Juvenile Penaeus monodon as effective zooplankton predators. Aquaculture. 103: 35-44.

Coman, F.E.; Connoly, R.M. \& Preston, N.P. 2003. Zooplankton and epibenthic fauna in shrimp ponds: factors influencing assemblage dynamics. Aquacult. Res. 34: 359-371.

Coman, F.E.; Connoly, R.M. \& Preston, N.P. 2006. Effects of water exchange and abiotic factors on zooplankton and epibenthic fauna in shrimp ponds. Aquacult. Res. 37: 1387-1399.

Delbare, D.; Dhert, P. \& Lavens, P. 1996. Zooplankton. In: Manual on the production and use of live food for aquaculture. FAO Fisheries Technical Paper. 252$281 \mathrm{pp}$. 
Durbin, E.G. \& Durbin, A.G. 1978. Length and weight relationships of Acartia clause from Narragansett Bay, R. I. Limnol. Oceanogr. 23 (5): 958-969.

FAO, 2006. The State of World Fisheries and Aquaculture. FAO Fisheries Department. Rome, Italy.

Garcia, C.A.E. 1997. Hydrographic Characteristics. In: Seeliger, U.; Odebrecht, C. \& Castello, J.P. (eds.) Subtropical Convergence Environments. Springer, Berlin. 18-20pp.

He, Z.H.; Qin, J.G.; Wang, Y.; Jiang, H. \& Wen, Z. 2001. Biology of Moina mongolica (Moinidae, Cladocera) and perspective as live food for marine fish larvae: review. Hydrobiologia457: 25-37.

Helland, S.; Terjesen, B.F. \& Berg, L. 2003. Free amino acid and protein content in the planktonic copepod Temora longicornis compared to Artemia franciscana. Aquaculture. 215: 213-228.

Margalef, R. 1983. Limnología. $1^{a}$ Edição. Omega, España, 1010p.

Martinez-Cordova, L.R.; Barraza, R. \& Pasten, N. 1997. Abundance, composition and nutritional contribution of zooplankton in fertilized and unfertilized shrimp aquaculture ponds with different feeding rates. J. Aqua. Trop. 12(1): 23-34.

Martinez-Cordova, L.R.; Campaña-Torres, A. \& PorchasCornejo, M.A. 2002. Promotion and contribution of biota in low water exchange ponds farming blue shrimp Litopenaeus stylirostris (Stimpson). Aquacult. Res. 33: 27-32.

Martinez-Cordova, L.R. \& Peña-Messina, E. 2005. Biotic communities and feeding habits of Litopenaeus vannamei (Boone 1931) and Litopenaeus stylirostris (Stimpson 1974) in monoculture and polyculture semi-intensive ponds. Aquacult. Res. 1-10.

Montú, M. 1980. Zooplâncton do Estuário da Lagoa dos Patos. Estrutura e variações temporais e espaciais da comunidade. Atlântica. 4:5372.

Montú, M.; Duarte, A.K. \& Gloeden, I.M. 1997. Zooplankton. In: Seeliger, U.; Odebrecht, C. \& Castello, J.P. (Eds.), Subtropical Convergence Environments. Springer, Berlin. 40-43pp.
Niencheski, L.F.H. \& Baumgarten, M.G. 1997. Environmental Chemistry. In: Seeliger, U.; Odebrecht, C. \& Castello, J.P. (Eds.), Subtropical Convergence Environments. Springer, Berlin. 20$24 p p$.

Nunes, A.J.P.; Gesteira, T.C.V. \& Goddard, S. 1997. Food ingestion and assimilation by the Southern brown shrimp Penaeus subtilis under semi-intensive culture in NE Brazil. Aquaculture. 149: 121-136.

Odum, E.P. 1986. Ecologia. Guanabara, Brasil, 434p.

Payne, M.F.; Rippingale, R.J. \& Longmore, R.B. 1998. Growth and survival of juvenile pipefish (Stigmatopora argus) fed live copepods with high and low HUFA content. Aquaculture. 194: 137-150.

Payne, M.F. \& Rippingale, R.J. 2000. Rearing West Australian seahorse, Hippocampus subelongatus, juveniles on copepod nauplii and enriched Artemia. Aquaculture. 188: 353-361.

Ponce-Palafox, J.; Martinez-Palacios, C.A. \& Ross, L.G. 1997. The effects of salinity and temperature on the growth and survival of juvenile white shrimp, Penaues vannamei, Boone, 1931. Aquaculture. 157: 107-115.

Preston, N.P.; Coman, F.E. \& Fry, V.M. 2003. Shrimp pond zooplankton dynamics and the efficiency of sampling effort. Aquacult. Res. 34: 373-381.

Rothlisberg, P.C. 1998. Aspects of penaid biology and ecology of relevance to aquaculture: a review. Aquaculture. 164: 49-65.

Sargent, J.R.; McEvoy, L.A. \& Bell, J.G. 1997. Requirements, presentation and sources of polyunsaturated fatty acids in marine larval feeds. Aquaculture. 155: 117-127.

Schipp, G.R.; Bosmans, J.M.P. \& Marshall, A.J. 1999. A method for hatchery culture of tropical calanoid copepods, Acartia spp. Aquaculture. 174: 81-88.

Stottrup, J.G. \& Nosker, N.H. 1997. Production and use of copepods in marine fish larviculture. Aquaculture. 155: 231-247.

Watanabe, T.; Katajima, C. \& Fujita, S. 1983. Nutritional value of live organisms used in Japan for mass propagation of fish: a review. Aquaculture. 34: 115143. 